\title{
Negative Impact of Abattoir Activities and Management in Residential Neighbourhoods in Kuala Terengganu, Malaysia
}

\author{
Auwalu Abdullahi ${ }^{1}$, Norizhar Kadarman ${ }^{1}$, Azmi Hassan ${ }^{2}$, Ibrahim Sulaiman Madobi ${ }^{3}$ \\ ${ }^{1}$ Faculty of Medicine, Department of Community Medicine, University Sultan Zainal Abidin (UniSZA), Kampus Kota, \\ Jalan Sultan Mahmud 20400 Kuala Terengganu, Malaysia \\ ${ }^{2}$ Institute for Community Development and Quality of Life (i-CODE), Universiti Sultan Zainal Abidin (UniSZA), \\ Kampus Gong Badak 21300 Kuala Terengganu, Terengganu, Malaysia \\ ${ }^{3}$ Audu Bako College of Agriculture Dambatta, Department of Animal Health and Husbandry, \\ P.M.B. 3159, Kano, Nigeria
}

\section{Article Info \\ Article history: \\ Received May 05, 2015 \\ Revised May 20, 2015 \\ Accepted May 29, 2015}

\section{Keyword:}

Abattoir

Cross Sectional Survey

Prevalence

Pollutant

\begin{abstract}
Poor management of abattoirs results in air and water pollution especially resident's in their close proximity. The objevtive of the study was to investigate the effect of poor management of abattoirs on the quality of life and health of residents in their vicinity. A cross sectional survey was conducted within two month period. Fifty six residents of buildings located approximately five kilometers radius to the abattoir were randomly selected for interview using questionnaire. Among the 56 residents interviewed, 20 $(35.7 \%)$ were sicked. Almost half $(33.9 \%)$ of the residents suspected the sickness to be related to abattoir hazards. The prevalence of diseases and symptoms experianced by the residents were typhoid fever $(14.4 \%)$, Diarhoea (12.5\%), Coughing (10.7\%), Asthma (8.9\%), Foot and Mouth Disease (7.1\%) and Dengue (3.6\%). The main associated factors of abattoir activities on residents 's health were contamination of air with pollutants (odds ratio, 15.52; 95\% confidence interval, 3.62-10.52), water contamination $(11.44 ; 3.17,12.28)$, gutters and drainages blockage $(6.35 ; 1.26,9.99)$ and prevention of children from outdoor activities $(4.65 ; 1.33,16.31)$. There was also reported case of food poisoning among the residents. Abattoir activities has direct and indirect negative effect on residents health who are in close proximity.
\end{abstract}

Copyright (C) 2015 Institute of Advanced Engineering and Science. All rights reserved.

\section{Corresponding Author:}

Auwalu Abdullahi,

Faculty of Medicine, Department of Community Medicine,

University Sultan Zainal Abidin (UniSZA),

Kampus Kota, Jalan Sultan Mahmud 20400 Kuala Terengganu, Malaysia.

Email: draakano930@gmail.com

\section{INTRODUCTION}

The provision of basic facilities and services in cities and neighborhoods is crucial to their sustainability and efficiency[1]. However, the disadvantage of locating some of these facilities in residential neighborhoods outweighs their advantages. Abattoir is one of such facilities. As a result of non-compliance with abattoir laws, residents around abattoir vicinity can be at a greater risk. The numerous waste and microbial organisms obtained during abattoir operation pose a significant challenge to the effective environmental management and are also associated with decreased quality of life of human population residing close to these abattoirs [2]. Air and water qualities within the residential areas are also affected by abattoir activities especially where modern or effective waste disposal system is not practiced [1]. Medical experts were reported by Oyedemi (2004) to have associated some diseases with abattoir activities which include pneumonia, diarrhea, typhoid fever, asthma, wool sorter diseases, respiratory and chest diseases [1]. 
Pathogens present in animal carcasses or shed in animal wastes may include rotaviruses, hepatitis $E$ virus, Salmonella spp., Escherichia coli O157:H7, Yersinia enterocolitica, Campylobacter spp, Cryptosporidium parvum, Mycobacterium spp and Giardia lamblia [3],[4].These zoonotic pathogens can exceed millions to billions per gram of feces and may infect humans through various routes such as contaminated air, contact with livestock animals or their waste products, exposure to potential vectors (such as flies, mosquitoes, water fowl, and rodents), or consumption of food or water contaminated by animal wastes [5]. The objective of this study was to investigate the impact of abattoir activities and management in residential neighbourhoods in Gong Badak, Terengganu, Malaysia.

\section{RESEARCH METHOD}

Study area

The study was conducted in Gong Badak Kuala Terengganu, Terengganu, Malaysia from January to February, 2015. It is located in the northern part of the city of Kuala Terengganu which has a total population of 337,553[6]. Gong Badak abattoir is situated within the industrial areas and surrounded from few metres by Supermarkets, residential houses and educational institutions. The abattoir performs most of their activities at morning from 3:00am to 8:00am. The major animals slaughtered were cattle and buffalos. Their operational activities are usually on demand by the community or during festivities.

A cross sectional survey was carried out within 2 month period. A total of 100 residents of buildings located approximately within 5 kilometers radius to the abattoir were randomly selected for interview using structured questionnaire; visual obsservation was also made to investigate the effects on their health.

\section{Data Collection}

Data was collected using a structured questionnaire consisting of two sections: Section A was designed to obtain socio demographic information of the respondents such as gender, age, marital status, ethnicity, educational level, employment status, house status, average hours spent at home, and period of been residing in the area. Section B consisted of questions regarding the effect of abattoir on residential neighbourhoods which include: several symptoms and diseases that may be associated with abattoir activities either through air borne, water borne or pollutants. Other questions were asked whether they suspect the diseases to be related abattoir hazards, their source of information, comfortability with the presence of abattoir in their surroundings, source of their drinking water, insects and flies disturbances, blockage of gutters or drainages by abattoir effluents and possible relocation due to negative effect of abattoir activities on their health. Section B utilised binary scale of 0 (No) or 1 (Yes).

\section{Data Analysis}

Data entry and analysis was done using Statistical Package for Social Science (SPSS) version 20.0 (Armonk, NY: IBM Corp.). Descriptive statistics was applied for all socio demographic data and presented as frequencies and percentages. Univariate and Multiple Logistic Regression ware used to determine the associated factors of abattoir activities on residents health. The level of significance $(\alpha)$ was set at $p<0.05$ for the study. From this study, the value of Cronbach's alpha reliability for the total scale was 0.87 .

\section{RESULTS AND ANALYSIS}

\section{Demographic characteristic of the respondents}

A total of 56 residents participated in the study giving a response rate of $56 \%$. Descriptive statistics of the samples were provided in Table 1. The mean age of the residents was 27.4 (7.1) years. The sample consisted of mostly male $64.3 \%$. Majority of the residents had attended Tertiary institutions $92.9 \%$ and $60.7 \%$ were single. Majority are unemployed (71.4\%). Most of them were Malay (55.4\%). However, the residents are either own a house or rent $41.1 \%$. The mean average time spent at home by the residents was 6.92 (4.8) hours and mean average duration of been living in abattoir vicinity was 6.71 (7.6) years. Fifty per cent of the residents either met the abattoir or it was established after they started living in the area. 
Table 1. Demographic characteristic of the respondents $(n=56)$

\begin{tabular}{|c|c|}
\hline Variable & no. $(\%)$ of the respondents \\
\hline Age, mean (SD) & $27.4(7.1)^{*}$ \\
\hline \multicolumn{2}{|l|}{ Gender } \\
\hline Male & $36(63.4)$ \\
\hline Female & $30(35.5)$ \\
\hline \multicolumn{2}{|l|}{ Educational level } \\
\hline \multicolumn{2}{|l|}{ No education } \\
\hline \multicolumn{2}{|l|}{ Primary education } \\
\hline Secondary education & $4(7.1)$ \\
\hline Tertiary education & $52(92.9)$ \\
\hline \multicolumn{2}{|l|}{ Marital status } \\
\hline Single & $34(60.7)$ \\
\hline Married & $18(32.1)$ \\
\hline Divorced & $4(7.1)$ \\
\hline \multicolumn{2}{|l|}{ Employment status } \\
\hline Employed & $16(28.6)$ \\
\hline Unemployed & $40(71.4)$ \\
\hline \multicolumn{2}{|l|}{ House status } \\
\hline Land lord (Owner) & $23(41.1)$ \\
\hline Tenant (Rental) & $23(41.1)$ \\
\hline Others & $10(17.9)$ \\
\hline \multicolumn{2}{|l|}{ Ethnicity } \\
\hline Malay & $31(55.4)$ \\
\hline Chinese & $2(3.6)$ \\
\hline Indians & $2(3.6)$ \\
\hline Others & $21(37.5)$ \\
\hline Average hours spent at home, mean (SD) & $6.92(4.8)^{*}$ \\
\hline Period of residing in the area, mean (SD) & $6.71(7.6)^{*}$ \\
\hline \multicolumn{2}{|l|}{ Met abattoir in the area } \\
\hline Yes & $28(50.0)$ \\
\hline No & $28(50.0)$ \\
\hline
\end{tabular}

Note: $* \mathrm{SD}=$ standard deviation

\section{The effect of abattoir activities and management on residential neighbourhoods}

About $67.9 \%$ of the abattoir residents were not comfortable with the presence of abattoir in their vicinity. The prevalence of Typhoid fever, Diarrhoea and Coughing were $14.4 \%, 12.5$ and $10.7 \%$ respectively (Table 2); these were the common problems in their area in which $33.9 \%$ believed to be associated with abattoir activities. There were also high number of flies, smelly odour, contamination of water with abattoir effluent, effect on breathing or cause respiratory diseases as well as blockage of gutters and drainages with waste materials from abattoir which account of about $42.9 \%, 55.4 \%, 30.4 \%, 41.1 \%$ and $26.8 \%$ respectively (Table 2). The major source of drinking water by the residents was tap water $83.9 \%$ while those of information were school and TV program $41.1 \%$ each (Table 2). The improper management of the abattoir affect their children outdoor activities said by $26.8 \%$ of the residents. However, $32.1 \%$ of the abattoir neighbouring community are likely to relocate from their houses as a result of poor management activities by the abattoir. Based on the interviewed made to the residents there were reported cases of diarrhoea, frequent coughing and incidences of food poisoning among the residents. 
Table 2. Effect of abattoir activities and management on residential neighbourhoods

\begin{tabular}{|c|c|c|}
\hline \multirow{2}{*}{ Variable } & \multicolumn{2}{|c|}{ Respondent Response; no. (\%)* } \\
\hline & No & Yes \\
\hline Happy with presence of abattoir & $38(67.9)$ & $18(32.1)$ \\
\hline Family sickness & $36(64.3)$ & $20(35.7)$ \\
\hline Typhoid fever & $48(85.7)$ & $8(14.4)$ \\
\hline Dengue & $54(96.4)$ & $2(3.6)$ \\
\hline Coughing & $50(89.3)$ & $6(10.7)$ \\
\hline Asthma & $51(91.1)$ & $5(8.9)$ \\
\hline Diarrhea & $49(89.5)$ & $7(12.5)$ \\
\hline Foot and mouth Disease & $52(92.9)$ & $4(7.1)$ \\
\hline Sickness due to abattoir hazards & $37(66.1)$ & $19(33.9)$ \\
\hline \multicolumn{3}{|l|}{ Source of information } \\
\hline Hospital & $41(73.2)$ & $15(26.8)$ \\
\hline School & $33(58.9)$ & $23(41.1)$ \\
\hline Family and Friends & $53(94.6)$ & $3(5.4)$ \\
\hline Radio program & $48(85.7)$ & $23(41.1)$ \\
\hline TV program & $33(58.9)$ & $41(73.2)$ \\
\hline Newspapers and magazine & $41(73.2)$ & $15(26.8)$ \\
\hline Internet & $49(87.5)$ & $7(12.5)$ \\
\hline Smell odor from abattoir & $25(44.6)$ & $31(55.4)$ \\
\hline Difficulty in breathing or respiratory diseases & $33(58.9)$ & $23(41.1)$ \\
\hline Prevent children outdoor activities & $41(73.2)$ & $15(26.8)$ \\
\hline \multicolumn{3}{|l|}{ Source of drinking water } \\
\hline Tap water & & $47(83.9)$ \\
\hline Bore holes & & $7(12.5)$ \\
\hline Well water & & $2(3.6)$ \\
\hline Contaminated water with abattoir effluents & $39(69.6)$ & $17(30.4)$ \\
\hline Blockages of gutters and drainages with waste materials & $41(73.2)$ & $15(26.8)$ \\
\hline High number of flies within the environment & $32(57.1)$ & $24(42.9)$ \\
\hline Relocation because of abattoir & $38(67.9)$ & $18(32.1)$ \\
\hline
\end{tabular}

no. $(\%)^{*}=$ number and percentages

Univariable analysis of factors associated with abattoir activities on residential neighbourhood's health

Table 3 illustrates the results of Univariable analysis of factors associated with abattoir activities on residents' health. The most important abattoir related, statistically significant associated factors identified on residents health were, contamination of air quality (odds ratio [OR], 15.52; 95\% CI, 3.62-10.52), contamination of water with abattoir effluents $11.44(3.17,12.28)$, blockage of gutters and drainages 6.35 $(1.26,9.99)$ and prevention of childrensfrom outdoor activities $4.65(1.33,16.31)$. However, odor smell from abattoir $1.47(0.34,6.34)$, higher number of flies $0.39(0.87,9.05)$ and possibility of relocation due to abattoir activities $2.80(0.96,10.07)$ were not statistically significant. After applying multiple logistic regression, some abattoir associated factors were removed by the analysis and they were not statistically significant.

Table 3. Univariable analysis of factors associated with abattoir activities on residential neighbourhood's health

\begin{tabular}{ccc}
\hline Factor & OR (95\% CL) & p-value \\
\hline Smell odour from abattoir & $1.47(0.34,6.34)$ & 0.604 \\
Contamination for air quality & $15.52(3.62,10.52)$ & $<0.001$ \\
Prevent children outdoor activities & $4.65(1.33,16.31)$ & 0.016 \\
Contamination of water with abattoir effluent & $11.44(3.17,12.28)$ & $<0.001$ \\
Blockages of gutters and drainages & $6.35(1.26,9.99)$ & 0.025 \\
High numbers of flies & $0.39(0.87,9.05)$ & 0.295 \\
Relocation due to abattoir activities & $2.80(0.96,10.07)$ & 0.085 \\
\hline
\end{tabular}

Note: $\mathrm{OR}=$ odds ratio.

$\mathrm{CI}=$ confidence interval

\section{Associated factors with abattoir activities on residential neighbourhood's health by Multiple Logistic Regression model}

Only 3 abattoir related factors on resident's health remained after Multiple Logistic Regression model was applied (Table 4). These were, contamination of air quality 15.52 (3.62-10.52), contamination of 
water with abattoir effluents $11.44(3.17,12.28)$ and blockage of gutters and drainages $6.35(1.26,9.99)$. These associated factors were all statistically significant.

Table 4. Associated factors with abattoir activities on residential neighbourhood's health by Multiple Logistic Regression model

\begin{tabular}{ccccc}
\hline Variable & $\begin{array}{c}\text { Regression } \\
\text { coefficient }\end{array}$ & $\begin{array}{c}\text { Adjusted odds Ratio } \\
(95 \% \text { a })\end{array}$ & $\begin{array}{c}\text { Wald } \\
\text { statistic }\end{array}$ & p-value \\
\hline Effect on air quality and breathing & 2.742 & $15.52(3.62,10.52)$ & 13.638 & $<0.001$ \\
Water contamination with effluent & 2.437 & $11.44(3.17,12.28)$ & 13.850 & $<0.001$ \\
Gutters and drainages blockages & 1.848 & $6.35(1.26,9.99)$ & 5.014 & 0.025 \\
\hline
\end{tabular}

Backward LR Multiple Logistic Regression model was applied

Multicolinearity and Interactions term were checked and not found

Hosmer-Lemeshow test, $(\mathrm{p}=0.342)$, classification table (overall correctly classified percentage $=86.5 \%$ ) and areas under the ROC curve $(85.8 \%)$ were applied to check the model fitness.

Our results indicated contamination of air with pollutants to be the major associated factor on resident's health as result of abattoir activities (41.1\%). Typhoid fever has higher prevalence among the diseases experienced by the residents in close proximity to abattoir environment. The cross sectional design used in this study concurrent with observation made to the abattoir neighbourhoods, medium sample size and engaging local facilitator increased the likelihood that the associated factors and diseases identified to be accurate In addition, our use appropriate statistical method and utilization of random sampling technique increases generalizability of our findings.

In this study there was significant association between abattoir effluents and diseases affecting abattoir neighbouring community (Table 3 and 4). According to [7] reported that abattoir effluents contain a lot of disease causing organisms. Similarly medical expert were reported to have associated some diseases with abattoir activities which include: pneumonia, diarrhoea, typhoid fever, asthma, wool sorter diseases, respiratory and chest diseases [1]. In this study few cases of typhoid fever, diarrhoea, respiratory diseases, coughing, foot and mouth diseases and dengue has been associated with abattoir activities (Table 2). These diseases can spread from the abattoir to the neighbouring community through vectors, animals or bye products of animal origin. Elevation of some symptoms among residents of intensive livestock operations which include: headache, running nose, sore throat, excessive coughing, shortness of breath, nausea or vomiting, diarrhoea, burning eyes, skin rash or irritation and decrease quality of life [8]. In this study excessive coughing, breathing difficulty, diarrhoea and decrease quality of life to the children of abattoir residents. Similar symptoms have been reported by [1] among the residents of abattoir neighbourhoods such as headache, excessive coughing, shortness of breath, heart burn, diarrhoea or dysentery, general body weakness, fever and typhoid fever.

In this study there was statistically significant contamination of air quality around the residents who are in close proximity to abattoir environment (Table 4). This may be associated with bad odour perceived from the abattoir environment which causes air pollution and possible transmission of air borne pathogens that result in respiratory diseases such as asthma and excessive coughing seen among the residents. Pollutants from abattoir activities have direct and indirect effects on human and the local built environment, especially those in close proximity to abattoir [1]. Adverse effect of abattoir activities which is of public health significance due to decrease health and quality of life of individual's residents around intensive livestock operations [8]. It was reported by [9] unused abattoir by-products were seen within the abattoir environment undergoing bacterial decomposition. This can pollute air quality resulting in transmission of pathogens and unpleasant odour to the abattoir neighbouring community.

The negative effects of gutters and drainages blockage by abattoir waste materials were statistically significant in this study (Table 3 and 4). Similar result was found by [1] in which bones, blood, dung and other waste materials were discharge to the nearby stream without treatment resulting in drainages blockages, pollution of surface and underground water. In addition, [10] Ayoola et al., 2012 reported that pollutant such as animal dung, refuse, domestic waste were not properly dumped leading to drainages blockages and causing hazardous effect to human existence and also to the health of the inhabitants of the area.

As in all survey studies, measurement of problems and differences between the abattoir neighbourhoods other than the exposure of interest could have influenced the results. However, biases are issues in any studies. It is possible that residents living in proximity to abattoir environment might report a greater number of symptoms and diseases because of negative feelings about the effect of the operation on

IJPHS Vol. 4, No. 2, June 2015: 124-130 
their lives and environment. This was observed to be limited or not have been done as some diseases not related to abattoir activities were included in the questions as a check. Study was not able to evaluate the levels of impact on residents within the same area but at a distance to abattoir. Possibility of different level of effect might varies due to differences in distance, building type, direction, physical barrier, amount of time spent at home and duration of living in abattoir vicinity. Quantitative evaluation of exposure differences between individuals would increase the ability of an epidemiologic study to identify health effects of air borne emissions.

The study was not able to evaluate the clinical or biological measures of outcome that would strengthen information about the relationships between resident's exposures to emissions from abattoir activities and their health. The study was also not able to evaluate specific population that may be more susceptible to health impact of environmental exposures from abattoir activities. Children, asthmatic and elderly individuals with decrease cardiovascular or pulmonary functions may be among the group within the populations.

\section{CONCLUSION}

The study found out that, abattoir activities have direct and indirect negative effects on the local built environment and people health especially abattoir neighbourhood residents. The study indicated contamination of air and water quality, possible transmission of diseases as well as blockages of gutters or drainages with abattoir effluents and other waste materials due the negative impact of abattoir activities on residential neighbourhoods. There were also limited outdoor activities by the children, increased number of flies around the area and chances of relocation by some the residents to another area free of abattoir settings. The abattoir management system should include a waste management plan designed for abattoir operation. Legislative measures with regards to land use, waste disposal methods, abattoir management, odour control and provision of assessment criteria for all abattoirs should be enforced. Effort should be made towards public awareness and enlightenment on possible impact of pollution from abattoir wastes by all relevant agencies when formulating new policies for better management.

Further research should be conducted to provide better understanding on the health effects of abattoir neighbouring community by combining individual's exposures assessment, clinical evaluation of human and mental health and periodic monitoring of exposed neighbouring community

\section{REFERENCES}

[1] Bello YO., Oyedemi DTA., "The impact of abattoir activities and management in residential neighbourhoods: A case study of Ogbomoso, Nigeria", J Soc Sci, vol/issue: 19(2), pp. 121-127, 2009.

[2] Adeyemo OK., "Unhygienic operations of a city abattoir in South Western Nigeria: Environmental implication", Ajeam/rage, vol/issue: 4(1), pp. 23-27, 2002.

[3] Sobsey MD., Khatib LA., Hill VR., Alocilja E., Pillai S., "Pathogens in animal wastes and theimpacts of waste management practices on their survival, transport, and fate", White paper for The National Center for Manure \& Agricultural Waste Management, 2002.

[4] Robinson P., Morris D., Antic R., "Mycobacterium bovis as an occupational hazard in abattoir workers", Aust N Z J Med, vol/issue: 18(5), pp. 701-3, 1988.

[5] Schlech WF., Lavigne PM., Bortolussi RA., "Epidemic listeriosis-evidence for transmission by food", The New England Journal of Medicine, vol. 308, pp. 203-206, 2005.

[6] Malaysian census, "Terengganu Basic Data (in Malay) Malaysian Concensus Department", 2010. Archieved from original on 2007-02-26. Available at http://www.evi.com/9/terengganu_population_2013. Accessed on 16 June, 2014.

[7] Roberts H., De jager L., Blight G., "Waste handling practices at red meat abattoirs in South Africa", Waste Management Resources, vol. 27, pp. 25 -30, 2009.

[8] Wing S., Wolf S., "Intensive livestock operations, Health and Quality of life among Eastern North Carolina Residents", Environmental Health Perspectives, vol. 108, pp. 233-238, 2000.

[9] Otolorin GR., Okolocha EC., Ameh VO., Mshelbwala P., Danjuma FA., Dzikwi AA., "Public Health Risk of Abattoir Operation at Zango Abattoir Zaria, Kaduna State Nigeria", Annual Research \& Review in Biology, vol/issue: 5(2), pp. 1-8, 2015.

[10] Ayoola PB., Adekeye EA., Jokanola OO., "Environmental Pollution and Control within Sabo area of Ogbomoso in Oyo State of Nigeria", IJRRAS, vol/issue: 10(2), pp. 329-338, 2012. 


\section{BIOGRAPHIES OF AUTHORS}

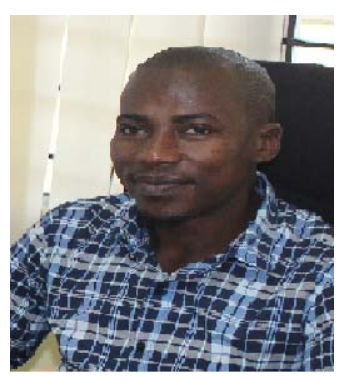

\section{Auwalu Abullahi}

$\checkmark$ University Sultan Zainal Abidin, Malaysia, Masters inview

$\checkmark$ Digital Bridge Institute, Kano 2013

$\checkmark$ Nigerian Institute of Management (NIM), FCE Centre, Gombe State. 2009 to2010

$\checkmark$ Usmanu Danfodio University Sokoto, Sokoto State, Nigeriafrom2001 to 2008

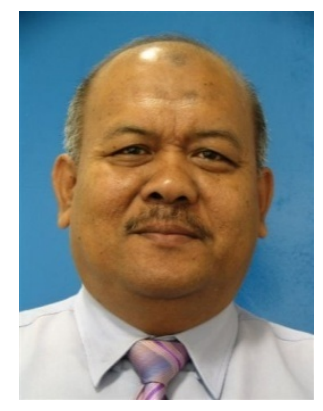

Associate Prof. Dr. Norizhar Kadarman

$\checkmark$ My present post is as an Associate Professor in the Public Health Department with Sultan Zainal Abidin University in Kuala Terengganu effective from 6 September 2012 to date

$\checkmark \quad$ I also attended a Basic Forensic Course conducted at Sultanah Aminah Hospital in Johore Bahru in 2005.

$\checkmark$. I received my Master Degree in Community Health from National University Malaysia in 1996 and majoring in Occupational Health.

$\checkmark \quad$ I studied Pharmacy course at Science University, Penang before continuing my Medical Degree at National University Malaysia and graduated in 1987

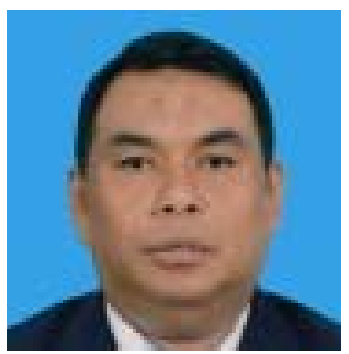

\section{Associate Prof. Dr. Azmi Hassan}

$\checkmark$ Director At Institut Pembangunan Komuniti Dan KualitiHidup, UniSZA

$\checkmark$ Graduated as medical Doctor from Universiti Kebangsaan Malaysia in 1988

$\checkmark$ Master in Community Medicine from Universiti Kebangsaan Malaysia. (MComM (OM) in1996

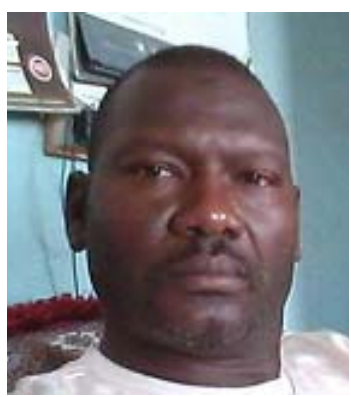

\section{Dr. Ibrahim Sulaiman Madobi}

$\checkmark$ Head of Department (Animal Science and Husbandry) Audu Bako College of Agriculture Danbatta, Kano State, Nigeria- 2013 to present.

$\checkmark$ PHD inview-Bayero University Kano (B.U.K.), Nigeria.

$\checkmark$ M sc. B.U.K. 2012

$\checkmark$ D.V.M. Usman Danfodiyo University Sokoto, Nigeria-1995 